\title{
PENGEMBANGAN MODEL MULTISENSORI BERBASIS TEKNOLOGI MULTIMEDIA UNTUK STIMULASI KEMAMPUAN LITERASI
}

\author{
Khikmah Novitasari ${ }^{1}$, Herdi Handoko ${ }^{2}$ \\ Fakultas Keguruan dan Ilmu Pendidikan Universitas PGRI Yogyakarta ${ }^{1}$, \\ Fakultas Keguruan dan Ilmu Pendidikan Universitas PGRI Yogyakarta ${ }^{2}$ \\ Email: khikmah@upy.ac.id ${ }^{1}$, herdi@upy.ac.id ${ }^{2}$
}

\begin{abstract}
Abstrak
Penelitian ini bertujuan untuk mengembangkan sebuah model pembelajaran multisensori berbasis teknologi multimedia dalam menstimulasi kemampuan literasi anak usia 5-6 tahun. Penelitian ini merupakan penelitian pengembangan dengan model pengambangan 4D (Define, Design, Develope, dan Deseminate). Berdasarkan hasil penilaian model dapat disimpulkan bahwa kualitas model pembelajaran multisensori berbasis teknologi multimedia secara umum adalah sangat baik dengan presentase keidealan mencapai 93,22\%. Artinya model pembelajaran ini layak digunakan untuk menstimulasi kemampuan literasi anak usia 5-6 tahun. Untuk mengetahui ada tidaknya peningkatan kemampuan literasi anak sebelum dan sesudah eksperimen dilakukan uji-paired sample $\mathrm{t}$ tes. Hasil dari uji paired sample $\mathrm{t}$ test ini menunjukkan nilai pretest diperoleh rata-rata 11,23 , sedangkan untuk nilai post test diperoleh nilai rata-rata 17,40. Nilai mean paired differences sebesar -6,167. Artinya, model multisensori berbasis teknologi multimedia ini efektif digunakan untuk meningkatkan kemampuan literasi anak usia 5-6 tahun.
\end{abstract}

Kata kunci: model pembelajaran, multisensori, multimedia, literasi anak usia dini

\begin{abstract}
This study aims to develop a multisensory learning model based on multimedia technology in stimulating the literacy skills of children aged 5-6 years. This research is a development study with a 4D floating model (Define, Design, Develope, and Deseminate). Based on the results of the model assessment it can be concluded that the quality of multisensory learning models based on multimedia technology in general is very good with the percentage of ideals reaching 93.22\%. This means that this learning model is appropriate to be used to stimulate the literacy skills of children aged 5-6 years. To find out whether or not there was an increase in children's literacy skills before and after the experiment a paired sample t-test was conducted. The results of the paired sample t test showed that pretest values were obtained on average 11.23, while for post test values an average value of 17.40 was obtained. The mean paired differences are 6,167. That is, this multimedia technology-based multisensory model is effectively used to improve the literacy ability of children aged 5-6 years.
\end{abstract}

Keywords: learning model, multisensory, multimedia, early childhood literacy.

http://jurnal.upmk.ac.id/index.php/pelitapaud 


\section{PENDAHULUAN}

Kemampuan literasi merupakan salah satu keterampilan yang dibutuhkan di abad 21. Keterampilan ini penting untuk mengelola informasi yang didapatkan seseorang. Kemampuan literasi juga dapat membantu seseorang dalam mengidentifikasi, mengevaluasi, mengatur, serta memanfaatkan informasi yang ia butuhkan. Selain itu, kemampuan literasi yang baikini juga sangat berguna untuk mengomunikasikan informasi dalam mengatasi masalah. Lebih dari sekedar memiliki kemampuan untuk membaca dan menulis, literasi adalah kemampuan anak untuk berkomunikasi dengan orang lain dan untuk memahami dunia (Setyawati \& Novitasari, 2019).

Kemajuan suatu negara berbanding lurus dengan kemampuan literasi masyarakatnya. Semakin tinggi literasi suatu bangsa, maka semakin tinggi pula tingkat kemajuan bangsa tersebut. Oleh sebab itu, dalam rangka menciptakan suatu bangsa yang maju, maka perlu membiasakan masyarakat untuk terpapar literasi sejak dini. Kemampuan literasi awal yang baik membantu anak lebih mudah belajar membaca dan meningkatkan kesuksesan anak di sekolah (Ruhaena, 2014: 1). Kemampuan literasi yang baik dapat memperluas cakrawala pengetahuan, memberikan inspirasi atau solusi bahkan membuka banyak peluang baru (Utami, dkk, 2019). Menurut Allington, kemampuan literasi awal yang dimiliki anak, dapat dijadikan prediksi kemampuan literasi anak tersebut pada tingkat sedang sampai tinggi (Trehearne, 2011: 34) Anak yang terbiasa mendapatkan stimulasi kemampuan literasi sejak dini akan menyebabkan anak menjadi seorang pebelajar sepanjang hidupnya.

Saat ini kemampuan literasi anak di Indonesia masi tergolong rendah. Indonesia menempati peringkat 64 dari total 72 negara di tahun 2018. Data tersebut diperoleh dari Program for International Student Assessment (PISA) mengenai tingkat literasi negara-negara dunia. Kenyataan itu menunjukkan lemahnya masyarakat Indonesia dalam menginterpretasikan sumber informasi. Maka, pelu ditemukan solusi terhadap masalah ini, agar tingkat literasi anak di Indonesia dapat meningkat di tahun-tahun berikutnya.

Sayangnya, saat ini masih ada orangtua yang kebingungan bagaimana menstimulasi kemampuan literasi anak dirumah. Orangtua saat ini menganggap 
tanggungjawab kemampuan akademik putera-puterinya ada penuh di tangan guru. Padahal, tanggungjawab utama dalam pengasuhan anak adalah di tangan orangtua. Hasil penelitian sebelumnya menunjukkan bahwa orangtua masih kesulitan dalam melakukan aktivitas literasi yang terstruktur dan sistematis di rumah. Mereka membutuhkan suatu model pembelajaran literasi yang dapat dilakukan di rumah dengan tepat.

Dalam menstimulasi kemampuan literasi anak, orangtua perlu memperhatikan karakteristik anak Karakteristik anak yang aktif bermain, bersifat egosentris, bersifat fisiognomis, dan memiliki kesatuan jasmani dan rohani yang hampir tidak terpisahkan, menjadi alasan agar pembelajaran di taman kanakkanak harus melibatkan banyak aktivitas bermain didalamnya (Novianti, dkk, 2019: 11).

Bermain merupakan kebutuhan utama bagi anak-anak. Permainan yang baik adalah yang dapat mendidik atau menstimulasi perkembangan anak tersebut. Permainan-permainan tersebut harus dapat mengaktifkan seluruh sensori anak. Hal ini disebabkan anak belajar mengenal dunia lewat panca inderanya melalui aktivitas bermain.
Dalam hal ini, model pembelajaran multisensori sangatlah tepat diterapkan pada anak usia dini. Multisensori terdiri dari dua kata yaitu multi dan sensori. "Multi" berarti lebih, sedangkan "sensori" berarti panca indera. Maka multisensori dapat diartikan lebih dari 1 indera. Anak usia dini, dapat belajar dengan baik, apabila materi pengajaran disajikan dalam berbagai modalitas alat indera. Modalitas yang dipakai tersebut antara lain; visual, auditoris, kinestetik, dan taktil, atau disingkat dengan VAKT (Yusuf , 2003: 95).

Selain itu, dalam pengembangan model pembelajaran juga perlu memperhatikan kemajuan ilmu pengetahuan dan teknologi yang terkini. Di era revolusi industri 4.0 ini perkembangan teknologi informasi dan komunikasi memegang peranan yang sangat penting. Penggunaan teknologi multimedia saat ini menjadi hal yang diperhatikan secara lebi dalam perkembangan media yang digunakan pada proses belajar dan mengajar di Taman Kanak-kanak. Teknologi multimedia ini menggabungkan berbagai media seperti: teks, numeric, suara, gambar, animasi dan video dalam satu software digital. Media ini juga dapat 
digunakan secara interaktif oleh anakanak. Teknologi multimedia ini sesuai dengan model pembelajaran multiensori yang sifatnya mengoptimalkan beberapa indera anak. Oleh sebab itu, peneliti mengembangkan model pembelajaran multisensori berbasis teknologi multimedia dalam pembelajaran literasi anak usia 5-6 tahun.

\section{METODE PENELITIAN}

\section{Jenis Penelitian}

Penelitian ini merupakan penelitian pengembangan, yang bertujuan untuk mengembangkan model multisensori berbasis teknologi multimedia dalam pembelajaran literasi anak usia 5-6 tahun. Produk yang dihasilkan prosedur ini tidak hanya buku panduan pembelajaran, akan tetapi juga menghasilkan CD Interaktif untuk pembelajaran literasi anak usia 5-6 tahun yang dapat digunakan orangtua di rumah. Model yang digunakan untuk dasar pengembangan media pembelajaran ini adalah model 4-D (define, design, develop, desseminate) yang ditemukan oleh Thiagarajan (1974:5).

\section{Waktu dan Tempat Penelitian}

Penelitian ini dilaksanakan di Kelurahan Patangpuluhan, Kecamatan Wirobrajan, Kota Yogyakarta. Analisis kebutuhan dan uji coba skala kecil telah dilaksanakan pada bulan Juni s.d Agustus tahun 2019, sedangkan uji coba lapangan dilaksanakan pada bulan oktober s.d November tahun 2019.

\section{Subjek Penelitian}

Subjek penelitian ini adalah anak usia 5-6 tahun dan orangtuanya. Penelitian ini melibatkan 80 orangtua dan anak dalam analisis kebutuhan, dan 30 orangtua dan anak untuk uji coba lapangan.

\section{Prosedur}

Prosedur penelitian dapat dilihat pada gambar 1 .

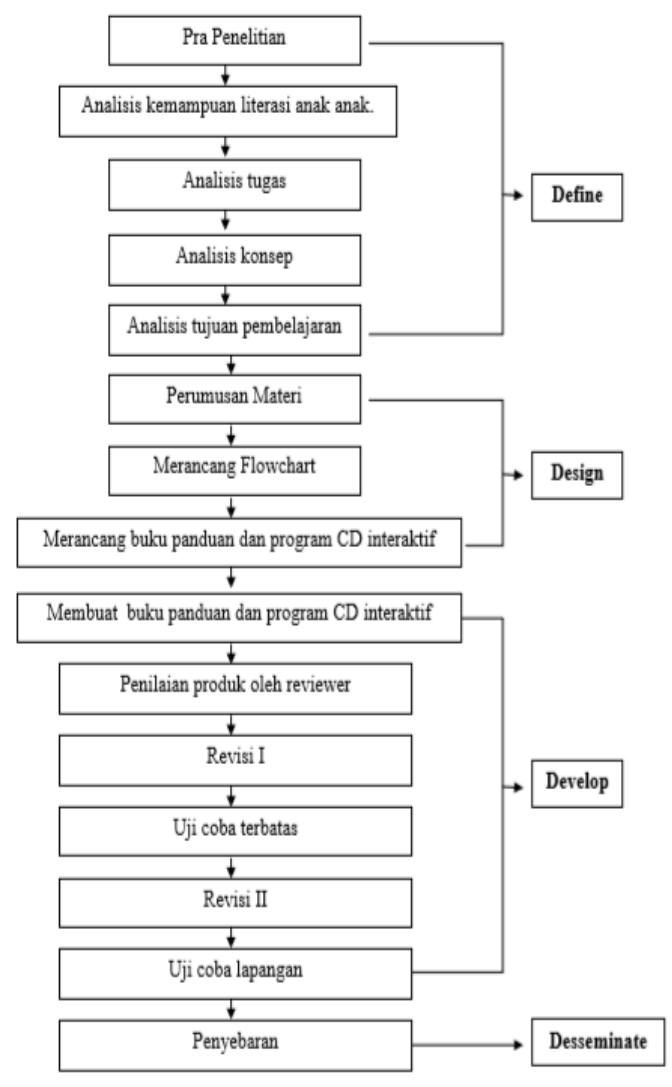

Gambar 1. Alur Penelitian 


\section{Data, Intrumen, dan Teknik Pengumpulan Data}

Data analisis kebutuhan diperoleh dari hasil angket dan Forum Group Discusion. Data uji coba skala kecil diperoleh dari 5 orang tua dan anak, serta data uji coba lapangan diperoleh dari 30 orangtua dan anak.

Instrumen kemampuan literasi yang digunakan adalah instrumen Get Ready To Read yang dikembangkan oleh Grover J. Whitehurts, PhD. Teknik pengumpulan data mengguakan random sampling.

\section{Teknik Analisis Data}

Analisis data menggunakan paired sample t test, untuk menguji perbedaan rata-rata skor pre test dan post test.

\section{HASIL PENELITIAN DAN} PEMBAHASAN

Dari hasil analisis kebutuhan yang telah diperoleh sebelumnya, maka untuk memenuhi kebutuhan orangtua dalam menstimulasi perkembangan literasi anak di rumah, dirumuskan suatu model stimulasi yang berdasar pada pendekatan belajar multisensori berbasis teknologi multimedia. Teknologi multimedia disini tidak menggantikan kegiatan yang penting untuk perkembangan anak, seperti bermain kreatif, , eksplorasi kehidupan nyata, aktivitas fisik, percakapandan interaksi sosial. Model tersebut dapat dilihat pada gambar 2 .

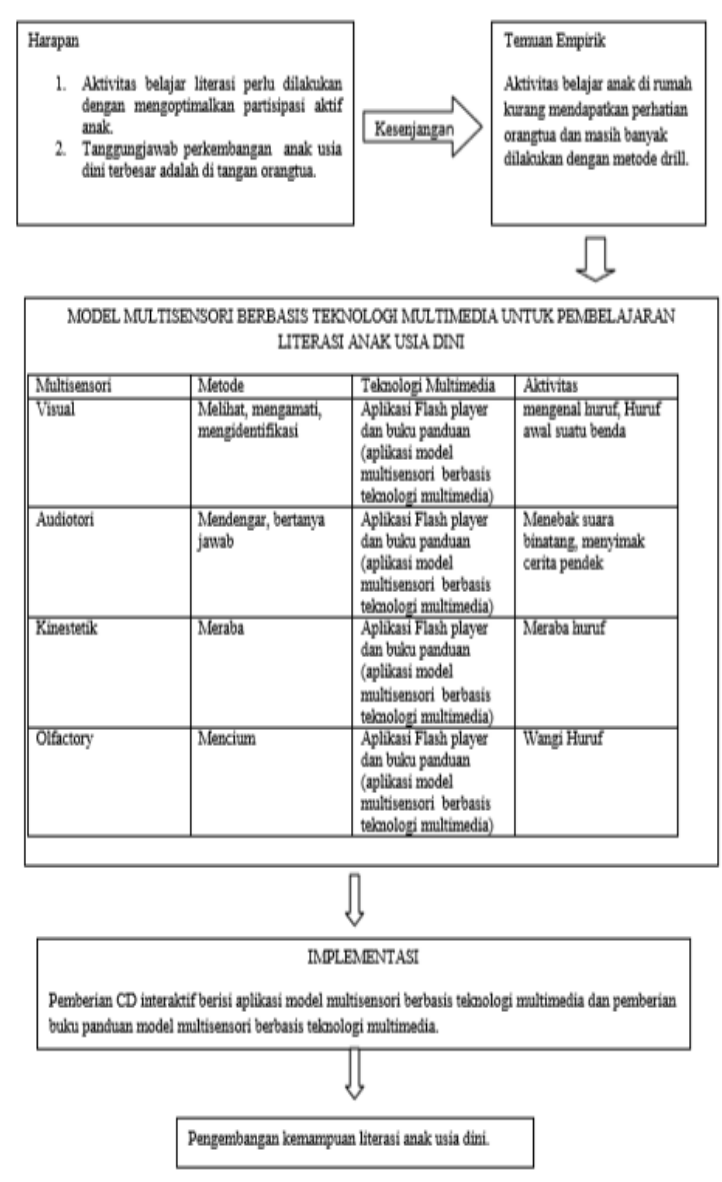

Gambar 2. Pengembangan model multisensori berbasis teknologi multimedia untuk pembelajaran literasi anak usia 5-6 tahun.

Adapun langkah-langkah dalam menggunakan model multisensori berbasis teknologi multimedia ini adalah sebagai berikut,

Pemusatan perhatian dan fokus, Sebelum mengoperasikan teknologi multimedia, 
orangtua perlu memusatkan perhatian anak agar siap untuk melakukan aktivitas literasi. cara memusatkan perhatian dapat dengan bercerita, bernyanyi atau tanyajawab.

Orientasi, Setelah anak siap untuk bermain dengan teknologi multimedia, orangtua perlu melakukan orientasi yaitu mengenalkan perangkat multimedia kepada anak (mialnya layar monitor, keyboard, mouse) serta memberikan

\begin{tabular}{|c|c|c|c|c|c|}
\hline \multirow[b]{2}{*}{ No. } & \multirow[b]{2}{*}{ Penilai } & \multicolumn{3}{|c|}{ Hasil Penilaian Komponen } & \multirow[b]{2}{*}{ Total } \\
\hline & & $\begin{array}{l}\text { Kelayakan } \\
\text { Isi }\end{array}$ & Kebahasaan & Penyajian & \\
\hline 1. & Validator 1 & 83 & 50 & 55 & 188 \\
\hline 2. & Validator 2 & 79 & 43 & 43 & 165 \\
\hline 3. & Validator 3 & 82 & 52 & 50 & 184 \\
\hline \multicolumn{2}{|c|}{ Jumlah } & 244 & 145 & 148 & 537 \\
\hline \multicolumn{2}{|c|}{ Rata-rata } & 81 & 48 & 49 & 179 \\
\hline \multicolumn{2}{|c|}{$\begin{array}{l}\text { Persentase } \\
\text { Keidealan }\end{array}$} & $96,68 \%$ & $92,94 \%$ & $98,64 \%$ & $93,22 \%$ \\
\hline \multicolumn{2}{|c|}{ Kategori } & $\begin{array}{l}\text { Sangat } \\
\text { Baik }\end{array}$ & Sangat Baik & $\begin{array}{l}\text { Sangat } \\
\text { Baik }\end{array}$ & $\begin{array}{l}\text { Sangat } \\
\text { Baik }\end{array}$ \\
\hline
\end{tabular}

pengetahuan kepada anak mengenai halhal yang berbahaya seperti listrik dan sebagainya.

Pemodelan, setelah anak mengetahui perangkat multimedia yang akan digunakan, selanjutnya orangtua mulai memberikan contoh bagaimana mengoperasikan model multisensori berbasis multimedia ini kepada anak.
Tahap bermain anak, pada tahap ini anak diberikan kesempatan untuk mengoperasikan teknologi multimedia tersebut sesuai dengan arahan orangtua sebelumnya.

Ringkasan, selanjutnya orangtua dan anak menyimpulkan secara ringkas apa yang telah dipelajarinya dari proses bermain sebelumnya, disini Anda juga dapat melakukan penilaian apakah anak mampu mempelajari materi literasi yang telah tersedia (Novitasari, 2017).

Desain

Produk

model

pembelajaran multisensori berbasis teknologi multimedia ini divalidasi oleh ahli model pembelajaran anak usia dini, ahli materi dan hali media. Proses validasi dilakukan dengan memberikan nilai pada angket penilian.

Tabel 1. Hasil Penilian model pembelajaran multisensori berbasis teknologi multimedia

Berdasarkan tabel, terlihat bahwa komponen kelayakan isi, kebahasaan, dan penyajian termasuk dalam kategori sangat baik dengan persentase keidealan secara berturut-turut adalah 96,68\%, 92,94\% dan 98,64\%. Berdasarkan hasil penilaian model dapat disimpulkan bahwa kualitas model pembelajaran multisensori berbasis teknologi multimedia secara umum adalah 
sangat baik dengan presentase keidealan mencapai 93,22\%. Draft I yang sudah direvisi dan dinilai oleh validator selanjutnya disebut Draft II yang nanti digunakan pada saat uji coba lapangan skala kecil.

Setelah divalidasi, kemudian peneliti melakukan uji coba terbatas. Sumber data dari uji coba terbatas ini adalah 5 orangtua dan 5 anak usia 5-6 tahun. Pengambilan sampel dilakukan berdasarkan teknik random sampling. Uji coba lapangan skala kecil dilaksanakan dilaksanakan pada tanggal 29 Juli 2019 di rumah masing-masing subjek penelitian pada jam pulang sekolah yaitu pukul 11.00 WIB. Orangtua diberikan paket model multisensori berbasis teknologi multimedia kemudan diberi angket oleh peneliti untuk menilai model tersebut.

Uji coba terbatas ini dilakukan untuk mendapatkan saran dan asukan dari orangtua. Saran dan kritik yang diperoleh dari orangtua pada uji coba terbatas antara lain: 1) orangtua menyukai konten-konten yang ada di dalam model, karena aktif melibatkan seluruh sensori aak dalam belajar, namun, pada konten wangi huruf, wangi yang diberikan pada salah satu huruf menyebar ke huruf lain, sehingga menjadikan rancu alam memilih jawaban.
Hendaknya per lembar hanya ada satu huruf saja sehingga bau huruf yang wangi tidak menyebar. 2) latar buku panduan sangat monoton, sedangkan anak-anak menyukai latar yang penuh warna. 3) aplikasi yang disediakan sangat menarik bagi anak, namun belum ada latar suara, hendaknya diberikan latar suara sehingga pembelajaran lebih menarik bagi anak.

Uji coba lapangan dilaksanakan pada 30 anak kelompok B beserta orangtuanya di TK ABA Patangpuluhan. Pengambilan sampel ini berdasarkan populasi penelitian, yaitu anak usia 5-6 tahun. Pembelajaran literasi dalam buku ini dirancang untuk anak usia 5-6 tahun. Materi dalam buku ini disesuaikan dengan tingkat pencapaian perkembangan literasi pada usia tersebut yang telah dijelaskan dalam Permendikbud No 137 Tahun 2014. Isi materi tersebut antara lain: 1) Menyebutkan simbol-simbol huruf yang dikenal, 2) Mengenal suara huruf awal dari nama benda-benda yang ada disekitarnya, 3) Menyebutkan kelompok gambar yang memiliki bunyi/huruf awal yang sama, 4) Memahami hubungan antara bunyi dan bentuk huruf, 5) Membaca nama sendiri, 6) Menuliskan nama sendiri, 7) Memahami arti kata dalam cerita. 
Pada saat uji coba lapangan, ke 30 anak tersebut dilakukan pretest kemampuan literasinya menggunakan instrumen "Get Ready To Read". Setelah itu, orangtua diberi buku panduan pembelajaran literasi dan $\mathrm{CD}$ interaktif, beserta lembar cheklist yang telah disiapkan oleh peneliti. Kemudian orangtua dibimbing untuk membaca buku panduan serta mengoperasikan CD interaktif tersebut pada laptop. Pada hari pertamaa, orangtua dan anak melakukan aktivitas pertama, yaitu menulis nama sendiri (diberikan waktu 5 menit), dilanjutkan dengan aktivitas kedua yaitu mengenal huruf (diberikan waktu selama 10 menit). Pada hari kedua, orangtua dan anak melakukan aktivitas ketiga yaitu meraba huruf (diberikan waktu selama 15 menit), dan aktivitas keempat yaitu wangi huruf (diberikan waktu selama 15 menit). Pada hari terakhir, yaitu hari ketiga, orangtua dan anak melakukan aktivitas kelima yaitu mengenal huruf awal suatu benda (diberikan waktu selama 15 menit), dan aktivitas keenam menyimak cerita (diberikan waktu selama 30 menit). Total waktu yang dibutuhkan untuk bermain literasi menggunakan model multisensori berbasis teknologi multimedia ini adalah 90 menit, yang terbagi dalam tiga hari. Di hari keempat peneliti melakukan post tes kepada seluruh subjek penelitian.

Untuk mengetahui ada tidaknya peningkatan kemampuan literasi anak sebelum dan sesudah eksperimen dilakukan uji-paired sample $\mathrm{t}$ tes. Uji paired sample $t$ test ini digunakan untuk membandingkn selisih dua mean dari dua sampel data. Namun sebelumnya dilakukan uji coba prasyarat terlebih dahulu yaitu uji normalitas. Pengujian normalitas berdasarkan pada hipotesis berikut.

Ho: sampel berasal dari populasi

berdistribusi normal

Ha: sampel tidak berasal dari populasi

berdistribusi normal

Normalitas terpenuhi atau Ho diterima dan $\mathrm{Ha}$ ditolak jika nilai signifikansi lebih dari 0.05. dari hasil uji normalitas, nilai signifikansi $\quad 0,091$ artinya lebih dari 0.05 , sehingga Ho diterima dan ha ditolak sehingga sampel berasal dari populasi berdistribusi normal.

Langkah berikutnya adalah melakukan uji pired sample test. Uji paired sample test ini untuk meguji hipotesis sebahai berikut.

Ho: tidak ada perbedaan rata-rata antara hasil belajar pre tes dengan post test, yang artinya tidak ada pengaruh 
penggunaan model multisensori berbasis teknologi multimedia pada pembelajaran literasi anak.

Nilai pretest diperoleh rata-rata 11,23, sedangkan untuk nilai post test diperolleh nilai rata-rata 17,40 . Jumlah anak yang digunakan sebanyak 30 anak. Karena nilai pre test < post test, maka artinya secara deskriptif ada perbedaan rata-rata kemampuan litersi anak.

Terdapat korelasi antara kedua hubungan variabel pre test dengan variabel post test. Berdasarkan output di atas dikethui nilai koefisien korelasi sebesar 0,756. Karena nilai sig 0,000> probabilitas 0,05 , maka dikatakan bahwa tidak ada hubungan antara variabel pre tes dan variabel post test

Dari hasil uji paired sample t test ietahui nilai sig. (2-tailed) adalah sebesar $0,000<0,05$, maka sesuai dengan pengambilan keputusan di atas dapat disimpulkan bahwa ho ditolak dan ha diterima. Nilai mean paired differences sebesar -6,167. Nilai ini menunjukkan selisih antara kemampuan literasi anak saat pre test dan saat post test. Artinya, model multisensori berbasis teknologi multimedia ini efektif digunakan untuk meningkatkan kemampuan literasi anak usia dini. Model pembelajaran yang aktif dan merangsang semua alat indera (multisensoris) lebih efektif bagi anak prasekolah karena sesuai dengan kebutuhan dan karakteristik psikologis anak (Ruhaena, 2008).

\section{SIMPULAN}

Dari hasil penelitian yang telah dipaparkan, diketahui bahwa model multisensori berbasis teknologi multimedia ini layak untuk digunakan orangtua dalam menstimulasi kemampuan literasi anak di rumah. Hasil uji paired sample $\mathrm{t}$ test juga menunjukkan bahwa model ini efektifdigunkan untuk meningkatkan kemampuan literasi anak usia 5-6 tahun.

\section{DAFTAR PUSTAKA}

Setiawati, E., \& Novitasari, K. (2019). Penguatan Literasi Sosial Anak Usia Dini Pada Siswa Sekolah PAUD Sejenis (SPS) Wortel di Bantulkarang, Ringinharjo, Bantul, Kabupaten Bantul. Jurnal Berdaya Mandiri, 1(1), 35-48.

Utami, N. R., Novitasari, K., Handoko, H., Sakti, S. A., \& Widyastuti, T. M. (2019). Pelatihan Pengembangan Strategi Pembelajaran Literasi Awal Pada Guru Taman Kanak-Kanak. Jurnal Berdaya Mandiri, 1(1), 9-18.

Novitasari, K. (2019). Penggunaan Teknologi Multimedia Pada Pembelajaran Literasi Anak Usia Dini. Jurnal Golden Age, 3(01), 50-56. 
Novitasari, K. (2017). Pembelajaran Berbasis Proyek untuk Menanamkan Karakter Tanggung Jawab pada Anak Kelompok B Di Tk Nasima Kota Semarang. PG PAUD Universitas PGRI Yogyakarta.

Ruhaena, L. (2008) Pengaruh Metode Pembelajaran Jolly Phonics terhadap Kemampuan Baca-tulis Permulaan Bahasa Indonesia dan Bahasa Inggris pada Anak Prasekolah. Jurnal Penelitian Humaniora, 9(2), 190-204.

Ruhaena, L., Kumara, A., Adiyanti, M. G., \& Helmi, A. F. (2014). Home literacy activities and early literacy skills achievement in indonesian family context. Paper presented at the Asian Association of Indegenous and Cultural Psychology Conference on Stress, Health, Well Being: Indegenous, Social and Cultural Perspective, Surakarta, Indonesia.

Thiagarajan, Sivasailam, dkk. (1974). Instructional Development for Training Teachers of Exceptional Children. Washinton DC: National Center for Improvement Educational System.

Trehearne, P. (2011). Learning to Write and Loving It!. USA: Library of Congress Cataloguing-in-Publication Data

Yusuf, M. 2003. Pendidikan bagi Anak dengan Problema Belajar. Solo: Tiga Serangkai Pustaka Mandiri 